\title{
TENUN KUBANG: \\ SEMANGAT MEMPERTAHANKAN SENI TRADISI DARI PENGARUH MODERNITAS
}

\author{
Dini Yanuarmi dan Widdiyanti*)
}

\begin{abstract}
This research is aimed at analysing the preservation and harmonisation Kubang weaving into development of technology and modernisation. Tenunan Kubang (Kubang weaving) as a traditional art does not necessarily mean as a piece of cloth woven from threads with certain designs, colours, and motives, yet it also contain the socio-cultural values of the area where it originates and develops. As a traditional art, every cloth possesses splendidly woven motives. The motives are used to be seamlessly woven with some certain, seemingly-tough level of difficulty by using the manual-traditional weaving equipment. The influences of modernisation are considered as an effort to preserve a sustainable tradition of Kubang weaving art. The Approaches in the analysis is emphasied on sociological aspects of Kubang weaving products. The data for the analysis are collected by using both the library research and field observation. The results indicated that the long run of the Kubang weaving had always been simultaneous to the change and development of the ages. Under the circumstances, Kubang weaving appeared as a creative, innovative, and competitive product that maintained cultural and traditional values. Without those values, Kubang weaving shall loose its identity and at the same time, shall be meaningless and abandoned by the society.
\end{abstract}

Keywords: Kubang Weaving, Traditional Art, Motives, Minangkabau

\section{PENDAHULUAN}

Tenun Kubang merupakan salah satu kerajinan tenunan tradisional yang ada di Sumatera Barat. Sebagai seni tradisi, tenunan bukan hanya sekedar sehelai kain yang ditenun dengan warna, benang dan tampilan desain motif yang indah. Lebih dari itu, dapat dijadikan sebagai saksi dan refleksi perjalanan kebudayaaan dari kelompok masyarakat yang menekuni dan menggunakannya. (Edy Utama, 2006:6)
Tenun Kubang sebagai seni tradisi yang diwariskan secara turun temurun telah melalui perjalanan panjang dengan jatuh bangun, timbul tenggelam, dan pasang surut masa kejayaannya. Keberadaan tenun Kubang hingga saat ini merupakan bentuk kerja keras dan kepedulian dalam mempertahankan dan menjaga keberlangsungan warisan budaya.

Sehelai kain tenun berupa bagian dari khasanah budaya Minangkabau, tidak

* Dini Yanuarmi dan Widdiyanti (diniyanuarmi@gmail.com), Staf Pengajar Program Studi Kriya Seni, Jurusan Kriya, Fakultas Seni Rupadan Desain, Institut Seni Indonesia Padangpanjang 
dapat dilepaskan dari budaya masyarakat pendukungnya. Tenun Kubang dikenal dengan ciri dan bentuk fisik kain, nilai budaya, adat istiadat dan petatah petitih yang tercermin melalui motif pada kain tenun. Makna yang tersirat pada sehelai kain tenun yang disampaikan melalui bentuk motif merupakan manifestasi budaya daerah tempat ia tumbuh. Bahkan eksistensi dan penciptaannya sejalan dengan keyakinan, pandangan hidup dan perilaku masyarakat penyertanya.

Tenun Kubang hari ini, adalah bentuk keterbukaan dalam menerima berbagai perubahan dan perkembangan yang terjadi. Setiap era atau zaman selalu memunculkan permasalahan baru, dan permasalahan baru selalu memerlukan representasi yang baru pula guna menghadirkan aktualitas. Kemampuan tenun Kubang menjawab tantangan yang dihadapkan, sehingga memunculkan cara untuk menghadirkan ide-ide dan konsepkonsep baru, apakah pada tataran praktis maupun konseptual. Tanpa adanya inovasi, maka tenunan menjadi tradisi yang tidak lagi punya arti, sehingga akan ditinggalkan oleh masyarakat pendukungnya.

Inovasi dan kreatifitas yang muncul pada tenun Kubang adalah tercipta produk baru dengan desain bentuk dan desain motif yang baru. Produk baru ditinjau dari desain bentuk dimaknai pengembangan bentuk produk mengikuti zamannya disesuaikan dengan kebutuhan. Sedangkan ditinjau dari desain motif, dimaknai sebagai pengembangan dari desain tradisi tanpa merusak dan menghilangkan jati diri dan makna yang tersirat. Sementara perkembangan dan perubahan tidak menyentuh ranah peralatan yang digunakan dalam membuat tenunan. Tenun Kubang sejak awal keberadaannya hingga sekarang tetap dengan ATBM nya (alat tenun bukan mesin), dikarenakan konsistensi dalam mempertahankan kualitas tenunan.

Teknologi modern hadir, masuk dan mempengaruhi seni tradisi tenun Kubang, kondisi ini tidak dapat dilepaskan dan diabaikan begitu saja. Tulisan ini melihat bagaimana upaya pelestarian tenun Kubang dalam mempertahankan dan menjaga keberlangsungan sebagai seni tradisi. Pendekatan yang digunakan adalah aspek sosiologis dan pengaruh dari keberadaan tenun Kubang. Metode pengumpulan data yang digunakan dalam menganalisis kajian berupa studi kepustakaan dan observasi lapangan.

\section{PEMBAHASAN DAN HASIL}

\section{Keberadaan Tenun Kubang}

Tenun Kubang sebagai seni tradisi sejak awal keberadaannya mengalami fluktuasi (naik turun) mengikuti zamannya. Ada masa di mana tenunan berada pada puncak kejayaan, namun ada pula masa memudarnya puncak kejayaan tenunan sebagai seni tradisi. Dalam ranah seni, kondisi seperti ini wajar adanya karena setiap era atau zaman selalu memunculkan permasalahan baru. Permasalahan baru selalu memerlukan representasi yang baru guna menghadirkan aktualitas. Menurut Dwi Marianto bahwa manusia mempunyai imaginasi dan hasrat untuk memperoleh hal-hal baru yang menyegarkan dan mencerahkan. Oleh karena itu, tanpa kebaruan, kreativitas, aktualitas, kejutan yang menyenangkan atau yang mengerikan 
sekalipun, seni akan jatuh menjadi sesuatu yang membosankan, tak lagi layak disebut sebagai seni, sebab esensi seni adalah kreativitas. Seni yang hanya dipenuhi ungkapan-ungkapan umum nan klise jadi repetisi yang statis, dan membosankan, atau jadi tradisi yang tidak lagi punya arti, sehingga akan ditinggalkan oleh masyarakat pendukungnya. (2015: 15)

Sesuai dengan kutipan di atas, tenun Kubang melewati masa pasang surut dalam perjalanan panjangnya sejak mulai dijadikan sebagai seni tradisi dalam lingkaran budaya masyarakat Kubang. Pada suatu masa tenun ini pernah popular yaitu sekitar tahun 1961 sampai 1967, kepopuleran tenun Kubang tidak hanya di Nusantara, namun dikenal sampai ke Semenanjung Malaysia. Hampir seluruh masyarakat yang ada di kenagarian Kubang terlibat dalam aktifitas sebagai perajin dan pekerja untuk menghasilkan produk tenunan andalan daerah mereka. Produk tenunan pada masa itu adalah berupa sarung palakat dan sarung bugis nya. Tantangan pada masa itu mampu dijawab dan dipenuhi oleh perajin sesuai dengan kebutuhan pada zamannya, sehingga daerah Kubang pada saat itu menjadi sentra tenun di Nusantara.

Masa kejayaan tenun Kubang yang amat popular dengan ide, konsep dan tampilan yang mampu menjawab kebutuhan zaman di masa itu mengalami kemunduran. Faktor penyebab terjadinya kemunduran pada masanya adalah ketersediaan bahan baku (benang tenun). Tidak tersedianya bahan baku benang yang terdapat di pasaran, menghambat proses produksi. Dalam tulisan Nova Yunita, dinyatakan bahwa setelah tahun 1967 tenun Kubang memasuki masa suram, dikarenakan impor benang terhenti. Berakibat tenun Kubang tidak dapat memenuhi permintaan pasar, dan produksi tenun otomatis ikut terhenti. (2015: 74) Dampak dari kemunduran tersebut adalah hampir seluruh perajin dan pekerja tenun kehilangan pekerjaan, yang mengakibatkan mereka beralih profesi untuk melangsungkan kehidupan.

Kemunduran tenun Kubang tidak berlangsung lama, semangat mempertahankan dan mengembangkan tenun dirasa sebagai keharusan bagi masyarakat pendukungnya agar seni tradisi tetap terjaga keberadaan dan keberlangsungannya. Pada tahun 1975, tenun mulai diproduksi kembali dengan munculnya inovasi baru dari segi desain motif dan desain bentuk. Perkembangan desain motif dan desain bentuk tenunan menjadi tolak ukur dalam persaingan di ranah tekstil tanah air. Tanpa adanya perubahan dan perkembangan bentuk dan motif tenun yang bersifat kebaruan dan penyegaran atas konsep dan tampilannya, maka seni tradisi tidak akan mampu menjawab kebutuhan zaman niscaya akan mengalami penurunan makna dan terpinggirkan. Kebaruan dan penyegaran atas konsep tampilan tenun Kubang adalah diciptakan produk yang kreatif dan inovatif dalam bentuk busana (baju, sarung, dan selendang) dan produk interior rumah tangga (taplak meja, sarung bantal kursi, hiasan dinding).

Masa surut tenun Kubang pun kembali terjadi yaitu memasuki tahun 1990an, pada masa itu permasalahan yang dihadapi adalah dari segi pemasaran. Hasil produksi tenun hanya ditampung oleh satu pasar saja, sehingga terjadi persaingan antar pemilik usaha. Persaingan antar 
pemilik usaha berdampak pada harga tenunan, yang mengakibatkan banyak pemilik usaha memilih mundur dari usahanya karena tidak mampu menjaga kualitas. (2005: 77) Masa surut tenun Kubang mendapat perhatian dari pemerintah daerah. Keinginan pihak terkait membangkitkan kembali tenunan sebagai seni tradisi masyarakat yang harus dijaga kelestariannya. Sambutan baik dari masyarakat, sehingga tenun Kubang sampai sekarang tetap terjaga keutuhannya. Keberhasilan dalam mempertahankan seni tradisi diraih melalui kerja keras, gigih dan berani mengambil resiko. Pada setiap jenjang karir memerlukan ketekunan, komitmen dan konsistensi.

\section{Seni Tradisi dan Teknologi}

Timbul dan berkembangnya seni budaya tidak lepas dari ciri khas, karakteristik, dan fenomena sosial kultural dalam kehidupan masyarakat, di tempat mana suatu cabang seni dilahirkan. Kehadiran karya seni juga dipengaruhi oleh kondisi lingkungan alam sekitarnya, alam juga dapat menjadi sumber ide yang membantu menyadarkan manusia atas kebesaran kuasa Tuhan, sekaligus menjadi pendorong tersalurnya kegiatan kreatif secara menyeluruh. Karya seni lahir berkat daya kreatifitas para pendahulu, penerusan tradisi keahlian ditempuh melalui sistem pewarisan turun temurun. (Gustami, 2007: 127-128) Tenun Kubang sebagai warisan budaya diperoleh melalui proses penurunan keahlian secara turun temurun dari para pendahulunya. Proses pewarisan senantiasa berlangsung hingga saat ini, sehingga tenunan sebagai kebudayaan tradisi tetap terpelihara keberadaannya.
Tenun Kubang sebagai seni tradisi menggunakan peralatan tradisional sebagai komponen pembentuknya, yaitu alat tenun tradisional yang dikenal ATBM (alat tenun bukan mesin). Perajin di Kubang membuat tenun mengandalkan alat tradisional secara manual. Meskipun pengaruh modernisasi menghasilkan alat tenun secara masinal yang dikenal dengan ATM (alat tenun mesin), namun tenun Kubang tetap menjaga warisan budaya dengan baik. Kualitas tenunan yang dihasilkan dengan menggunakan ATBM dan ATM jelas berbeda, sehingga perajin Kubang tidak beralih pada ATM. Sejalan dengan kutipan Bernhard Bart bahwa peralatan ATBM dapat ditemukan di daerah Silungkang dan Kubang. Alat ini dapat dioperasionalkan dengan baik untuk membuat tenunan, meskipun untuk membuat motif pada tenun ATBM sangat sulit dan membutuhkan waktu lama. (2006: 104) Proses membuat motif tenunan dapat dilihat pada gambar di bawah,

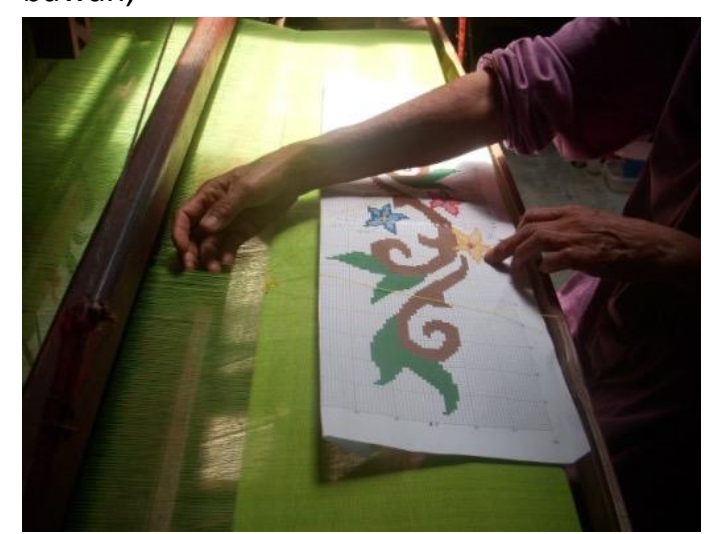

Gambar 1. Proses menenun (membuat motif) (Dokumentasi: Dini Yanuarmi, 2016)

Motif pada tenun Kubang tidak sekedar hiasan dan membuatnya indah, melainkan refleksi ajaran filosofi adat dan kebudayaan Minangkabau. Proses pembentukan motif dilakukan secara 
manual, dikenal dengan istilah mancukia atau menyungkit (gambar 1). Bagi perajin tenun yang sudah akrab dengan motif tradisi, tidak butuh waktu lama dalam proses membuat motif (mancukia). Berbeda dengan motif yang didesain baru, perajin membutuhkan konsentrasi dan ketelitian supaya hasil tenunan sesuai dengan desain.

Desain motif tenun Kubang menggunakan sistem komputerisasi, sehingga perancangan lebih cepat dan praktis. Tuntutan pasar mengharuskan tenunan ini hadir dengan rancangan motif yang aktual berbau tradisi. Sentuhan teknologi mampu menjawab tantangan kebutuhan pasar terhadap tenun Kubang sebagai seni tradisi. Menurut Couto ternyata seni memiliki kesejajaran dengan teknologi, dilihat dari perspektif proses kreatif. Seni merupakan suatu proses penciptaan artefak yang diawali oleh ide, konsep sampai ke artefak (materi), begitu juga teknologi. Keduanya memiliki kemiripan, karena memiliki orientasi yang sama, dari konsep ke produksi benda nyata. (2008: 32-33)

Masuknya pengaruh modernisasi dalam hal teknologi komputerisasi desain motif, menjadikan tenun Kubang semakin dikenal dan dilirik pasar. Kebutuhan terhadap tenunan, mengakibatkan selera estetis terhadap desain motif pun meningkat. Desain motif dengan sistem komputerisasi memberikan banyak kemudahan bagi perajin pemilik usaha dan desainer dalam membuat tenunan. Meskipun pengaruh globalisasi terhadap perkembangan tenun terjadi, namun motif tenun Kubang senantiasa beranjak dari motif-motif tradisi, sehingga nilai-nilai budaya daerah tetap terjaga keberlangsungannya. Dapat dilihat pada salah satu rancangan di bawah ini,

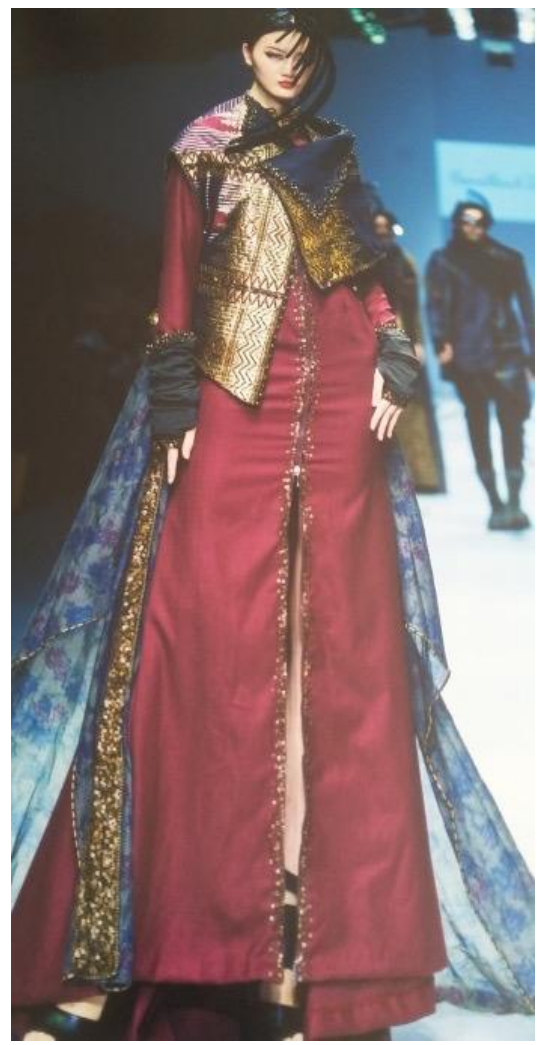

Gambar 2. Tenun Kubang rancangan Fomalhaut Zamel (Dokumentasi Tenun Kubang H. Ridwan)

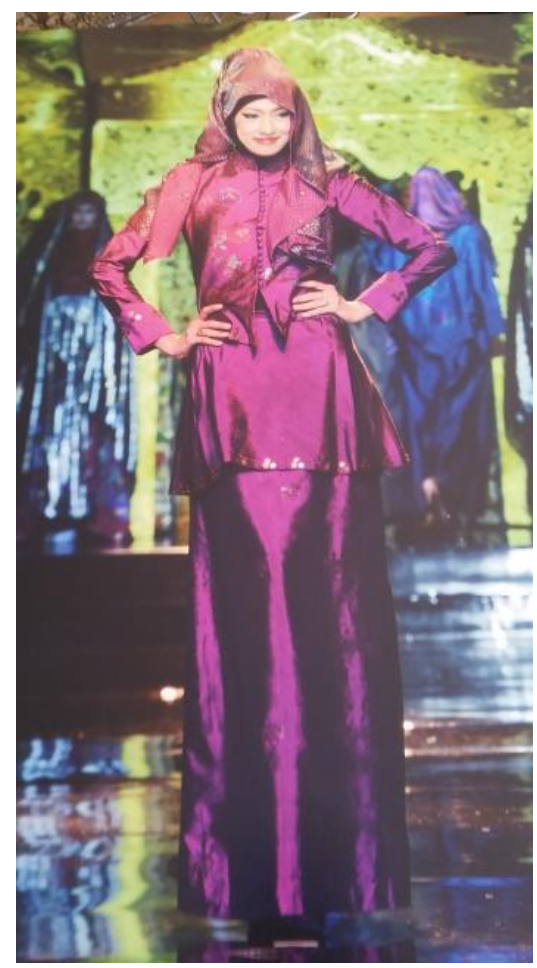


Gambar 3. Tenun Kubang koleksi H. Ridwan

(Dokumentasi Tenun Kubang H. Ridwan)

\section{Langkah Strategis dan Identitas}

Dalam tulisan Gustami bahwa, Modernisasi bagai virus mental yang menjalar merasuk ke seluruh sendi kehidupan umat manusia. Dalam kondisi seperti itu, kriyawan Indonesia harus bersikap kritis, analitis, selektif dan cerdas, serta arif dan bijaksana dalam menanggapai perubahan yang terjadi, termasuk dalam proses cipta seni. Dengan demikian, mereka dapat menghadirkan karya yang kreatif dan inovatif sesuai jiwa zaman tanpa meninggalkan nilai luhur budaya bangsa....Kriyawan perlu peka terhadap perubahan, juga cekatan menemukan solusi dengan cara mensinergikan pengaruh pembaruan dengan kearifan lokal hingga meraih keberhasilan. (2009: 47)

Tenun Kubang dalam hal ini menghadapi kompetisi dengan dunia mode secara global. Keberhasilan pada kompetisi tersebut diraih melalui kerja keras, gigih dan berani mengambil resiko. Ketekunan, komitmen dan konsistensi menjadi tolak ukur dalam pencapaian di setiap jenjang karir. Keberhasilan sangat ditentukan oleh besar kuatnya idealisme masyarakat pendukung tenun Kubang dalam memperjuangkan cita-cita mereka. Semua itu memerlukan persyaratan tertentu sejalan dengan kompensasi yang menjanjikan bagi tercapainya kesejahteraan perajin bersama dengan pemilik usaha.

Langkah strategis telah, sedang dan tetap akan dilakukan oleh perajin bersamasama dengan pemilik usaha, desainer dan pemerintah terkait dalam menjaga keberlangsungan dan mengembangkan seni tradisi adiluhung yang diwariskan oleh para pendahulu. Masuknya pengaruh modernitas, tidak menjadikan tenun Kubang kehilangan jati diri dalam melangkah menuju titik kejayaannya kembali. Bahkan hal tersebut dijadikan sebagai tradisi, seperti yang dikutip dalam Couto bahwa modernisasi telah mengubah kehidupan masyarakat tradisional Minangkabau, bahkan ada pendapat yang menyatakan modernisasi adalah suatu tradisi bagi masyarakat Minangkabau. Hal tersebut sudah berlangsung lama sejak zaman kolonial, yang membuahkan Bung Hatta dan Agus Salim, atau sejak islam yang membuahkan Imam Bonjol, dan lebih jauh lagi pada zaman lampau, yaitu pembaharuan yang dilakukan oleh Datuak Parpatiah Nan Sabatang dan Datuak Katumanggungan yang melahirkan budaya Minangkabau. (2008:118).

Tenun Kubang sebagai salah satu kebanggaan masyarakat Minangkabau tampil dengan desain motif yang mengandung unsur simbolik, fungsi dan estetik, bermuara pada kerangka "alam takambang jadi guru" dalam tradisi dialektika kultural daerahnya. Alam senantiasa dijadikan arah, pedoman perbuatan, tindakan dan perilaku dalam menyesuaikan diri dengan lingkungannya. Desain motif tetap dipertahankan dan meskipun mengalami pengembangan, namun tidak menghilangkan cita rasa estetik berbau tradisi.

Sehelai tenunan ternyata tidak hanya tampilan secara visual saja, namun lebih dari itu memiliki makna sebagai ruang ekspresi untuk menuturkan gagasan dan nilai-nilai yang dikristalisasikan dalam bentuk, motif dan warna. Terdapat tiga hal 
berkenaan dengan tenunan, pertama adalah tenunan sebagai seni tradisi yang dibuat secara rumit dari segi teknis dibutuhkan kesabaran dan ketelitian. Kedua, desain motif yang indah bermuatan nilai-nilai berupa simbol yang berakar dari alam. Ketiga, pengerjaan dan pembuatan tenunan diyakini sebagai pelindung martabat perempuan, baik sebagai pelaku (perajin) maupun sebagai pemakai (pengguna). (Jupriani, 2006: 70-71).

\section{PENUTUP}

Daerah Kubang sebagai salah satu sentra tradisi tenunan di Sumatera Barat menyimpan kreatifitas berkesenian masyarakatnya. Kekhasan dan keunikan tenunan memiliki perbedaan dengan tenunan dari daerah lain yang ada di dalam maupun luar Sumatera Barat. Di antara perbedaan yang ada menjadikan tenun Kubang memiliki ciri dan keunggulannya sendiri. Keahlian dan keterampilan di bidang tekstil ini terbukti memberikan manfaat positif bagi kelangsungan hidup masyarakat yang menekuninya. Merupakan suatu tantangan untuk memenuhi permintaan kebutuhan hidup masyarakat dan mendorong berkembangnya daya cipta. Aktivitas penciptaan terkait dengan pertimbangan ideologi sesuai jiwa zamannya, disertai pemikiran rasional untuk menciptakan selembar kain tenun yang estetis, kreatif, inovatif, efektif dan efisien, yang didasari perasaan estetik dan simbolik.

Tenun Kubang sebagai seni tradisi kreatif, yang dibutuhkan bukanlah penyeragaman, standarisasi dan penyamaan perspektif. Melainkan keluwesan berpikir, keberanian dan kemauan untuk menghadirkan lembaran demi lembaran kain tenun yang khas, unik, khusus atau istimewa, guna menawarkan kebaruan, penyegaran dan inovasi. Kreativitas dari selembar kain tenun tidak mesti berasal dari keadaan kondusif dengan fasilitas berupa peralatan yang memadai atau modern. Justru dengan peralatan tradisional berupa ATBM nya daya kreatif dapat muncul, guna memenuhi kebutuhan.

\section{DAFTAR PUSTAKA}

M. Dwi Marianto, Art and Levitation Seni dalam Cakrawala, Yogyakarta: Pohon Cahaya, 2015.

Nova Yunita, "Eksistensi Tenunan Kubang dan Upaya Pelestarian", Tesis memperoleh gelar S-2, Padang: Universitas Negeri Padang, 2015.

SP. Gustami, "Pendidikan Seni Kriya di Era Budaya Global: Merenda Nilai dan Identitas Budaya lokal" dalam jurnal Ekspresi Seni Jurnal IImu Pengetahuan dan Karya Seni, Vol. 11 No 1, Padangpanjang: ISI Padangpanjang, 2009.

Butir-Butir Mutiara Estetika Timur: Ide Dasar Penciptaan Seni Kriya Indonesia, Yogyakarta: Prasista, 2007.

Bernhard Bart, "Karok Motif, Perangkat Penting Revitalisasi" dalam Revitalisasi Songket Lama Minangkabau, Padang: Studio Songket Erika Rianti, 2006. 
24 ] CORAK Jurnal Seni Kriya Vol. 5 No.1, Mei-Okteber 2016

Nasbahry Couto, Budaya Visual Seni tradisi

Minangkabau, Padang: UNP Press

Padang, 2008. 